\title{
Preserve the Memory of San Francisco's Victorian Architecture
}

\author{
Caterina Morganti \\ Cecilia Mazzoli \\ Cristiana Bartolomei \\ Dominique Rissolo \\ Falko Kuester
}

\section{Abstract}

The article deals with the topic of photogrammetry applied to the historical architecture of San Francisco, one of the iconic buildings of the so-called Painted Ladies. These buildings are Victorian and Edwardian houses and buildings repainted, in different colors that embellish or enhance their architectural details, starting in the 1960s. The document will address a methodological discussion concerning the construction of parametric models of historic buildings. The research is prompted by the modern need to have databases full of exhaustive information, through which we can preserve the memory of the historical heritage present in the Californian reality, monitoring conditions and planning the future.
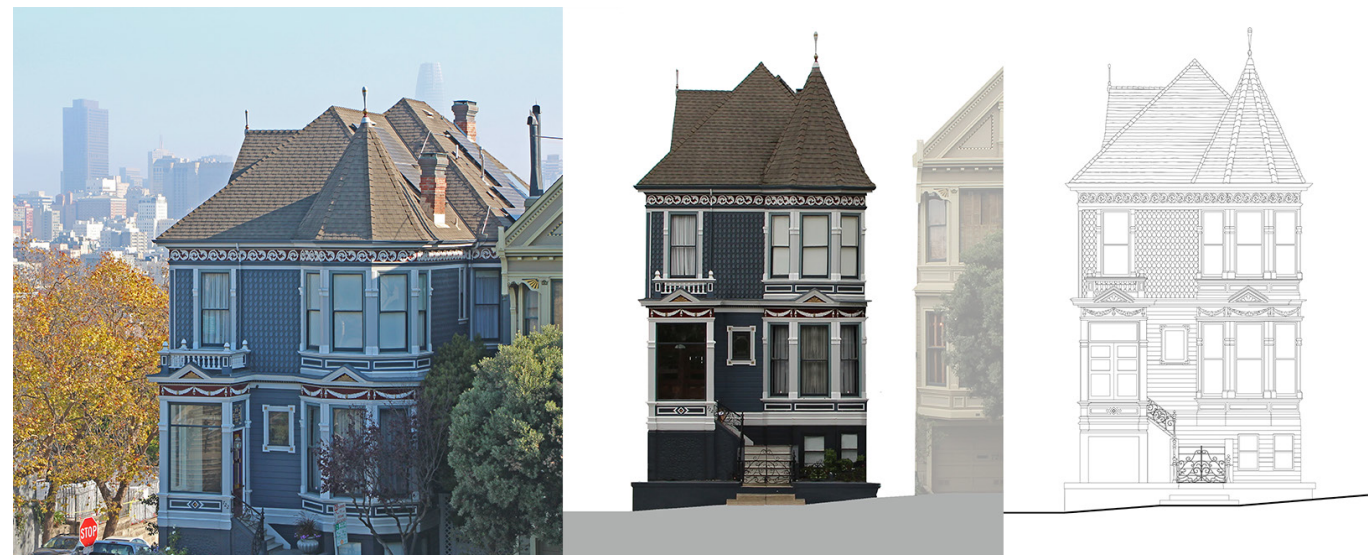
The architecture of San Francisco is not known for defining a particular architectural style, rather for, its interesting and challenging diversity topology and geography. San Francisco is known worldwide for its particularly eclectic mix of Victorian and modern architecture (fig. I).

The full story of the architecture of San Francisco is very complex; in particular, San Francisco participated to the international architectural trends from the second half of the nineteenth century.

Architectural styles also overlapped in the 19th century. Although some people were building houses in the latest style, others were more conservative and clung to past fashions. Some buildings combined more than one style, especially in the mid-1880s, when the Eastlake style fused with the emerging Queen Anne Style.

The earliest houses in Gold Rush San Francisco were plain clapboard, freestanding dwellings crowded together around the harbour.

As the port boomed, city designers laid out a series of grids over the steeply hilly site, heedless of the shape of the land.

Homestead associations bought these blocks and subdivided them into narrow house lots, generally I 00 feet deep and 25 feet wide. On these constricted sites builders shoehorned long, narrow wood houses that came out almost to the sidewalk but left a small yard to the rear.

The architectural styles present in San Francisco are different and very varied.

The Victorian period began in California in the late 1840s with simple, almost style less wooden houses, but subsequently the architectural styles that were born in San Francisco were different and various. The main identifiable architectural styles are: the Greek Revival, the Gothic Revival, the Italianate Style, the Eastlake Style (or Stick Style), the Queen Anne Style, the Shingle Style (fig. 2).

The Greek Revival landed in San Francisco in the 1850s. Classic Greek temples with their majestic columns inspired this style. This style is characterized by simple box columns without elaborately carved capitals, the buildings were generally symmetrical and sober. Rooms were usually rectangular and building plans quite simple. Only a few of these buildings still survive in San Francisco, in the Mission District and at Fort Mason and the Presidio. The Gothic Revival came following the Greek Revival. This style is characterized by pointed arch windows and delight in turrets. Very few Gothic Revival houses still survive in San Francisco. In the California countryside simplified Gothic Revival farmhouses with steeply pitched roofs, hooded dormers, and windows with pointed arch tops survive here and there. This style became the preferred style for Christian churches and collegiate ivory towers.

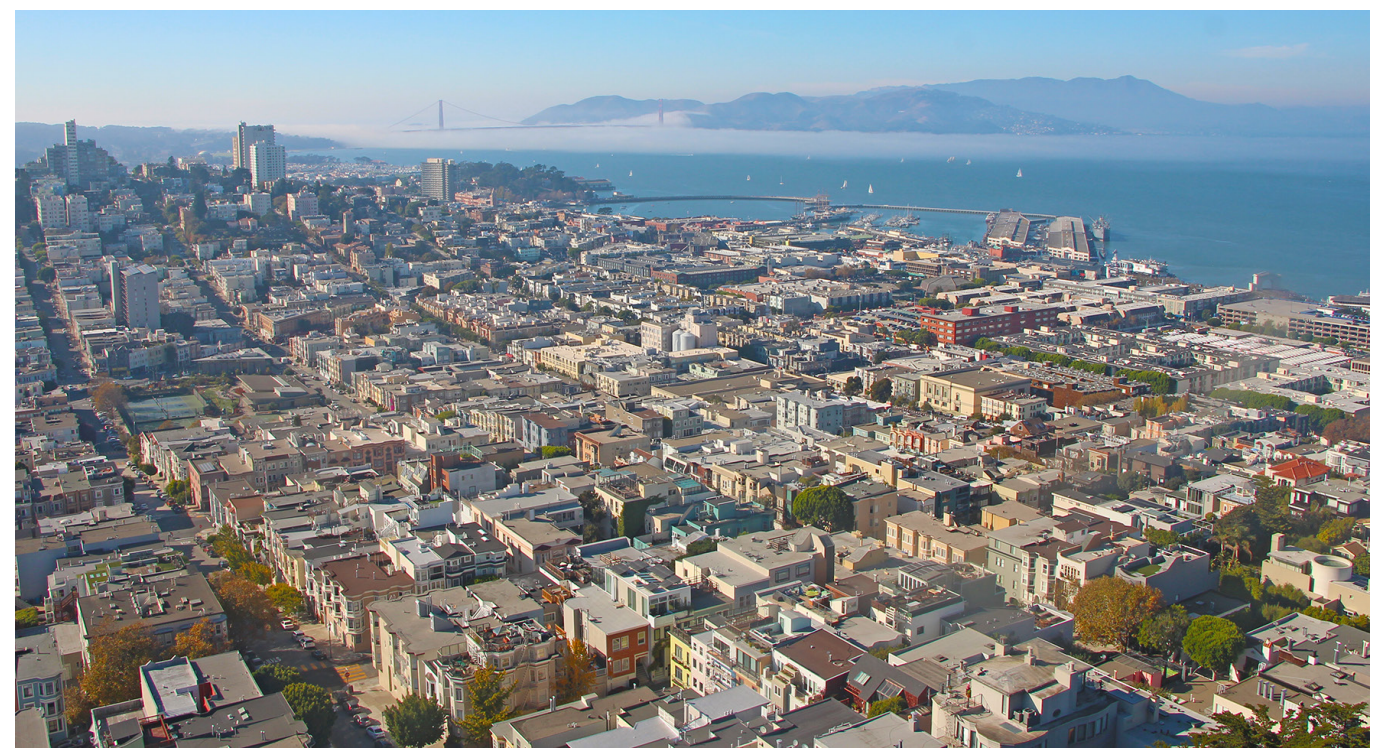


The Italianate Style (I860- | 880) has its stylistic roots in the robust, high-style stone buildings of the Italian Renaissance in its mannerist phase.

The main features of this style are the emphasis on vertical movement, with tall and narrow windows, classical ornaments, such as Corinthian columns.

The original exteriors were usually painted gray or beige, just to imitate the Italian noble palaces.

The buildings were built by stone or stucco-covered brick. In San Francisco the Italianate Style was adopted for the proliferating middleclass row houses, almost all of which were built of wood.

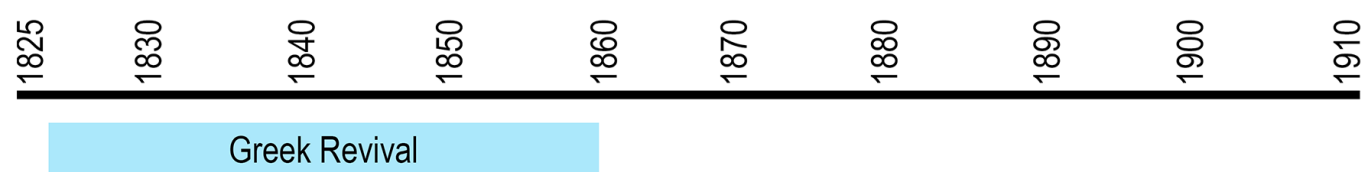

Greek Revival

\begin{tabular}{c} 
Gothic Revival \\
$\qquad \begin{array}{c}\text { Italianate Style } \\
\text { Eastlake Style }\end{array}$ \\
\hline
\end{tabular}

A distinguishing feature of Italianate design was the use of quoins, blocks of wood placed along the edges of facades in imitation of corner stonework. During the period of Italianate Style bay windows became popular. Italianate bay windows usually had three equal sized windows with the two side windows placed at an angle. Many Italianate row houses were built in San Francisco in the 1870s, and quite a few have survived.

The Eastlake Style (or Stick Style) took its name from the London furniture designer and popular writer Sir Charles Lock Eastlake. The main characteristics of this style are the creative use of wood for the production of ornaments, the presence of a pitched roof and rectangular bay windows.

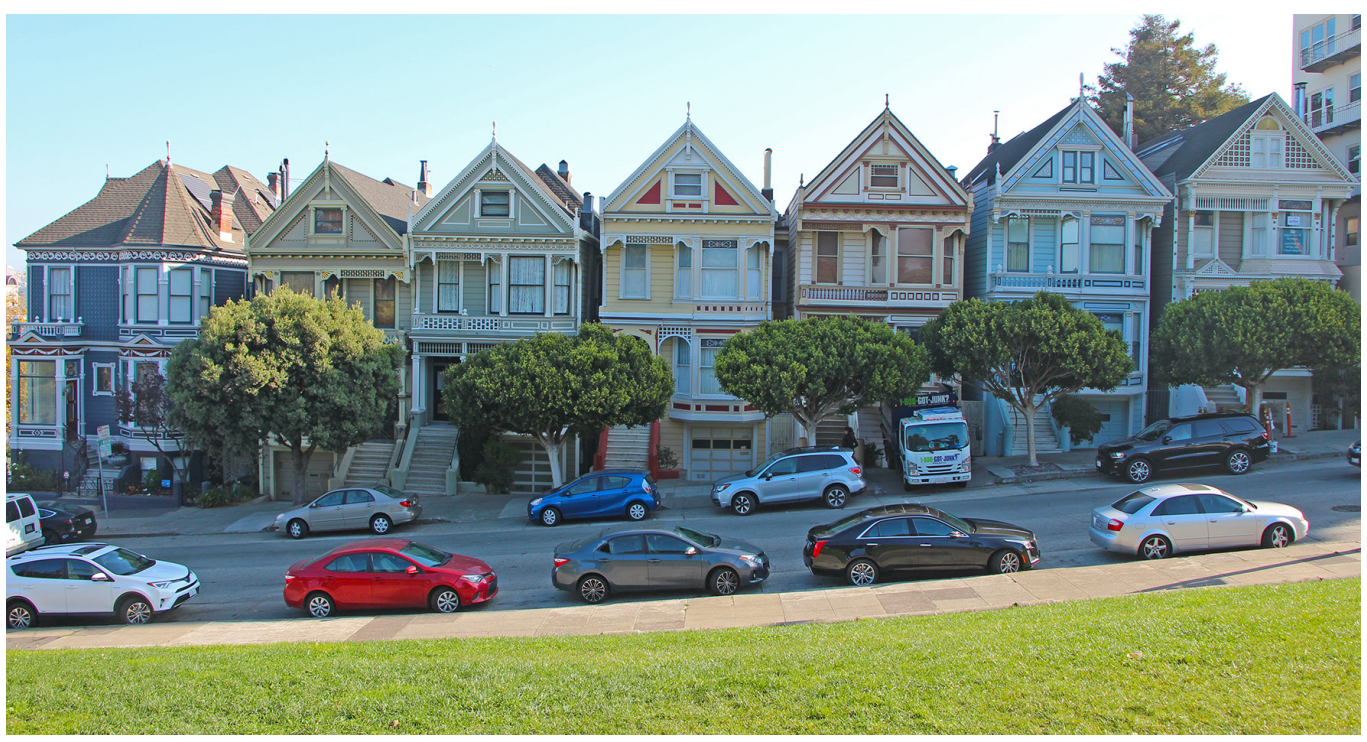


Eastlake houses have a marked angularity. They often have right-angled decorative woodwork and seem to express their underlying wood frame construction through their nailed on exterior decoration. This is what gives them the nickname Stick Style. Ornament is frequently incised, that is carved into the surface of the wood rather than projecting out from it.

This type of houses could be simple or very creative.

Bay windows in the 1880 s went from slant sided to rectangular in plan, making the bays larger and more useful from within. Eastlake houses of the late 1880s were frequently richly decorated. It was then that true architectural madness was achieved. Increasing was the presence of varied room shapes, asymmetrical exteriors, and rich ornament. This period was the culmination of new mechanical inventions for woodworking. Window frames, doors, brackets, columns and cornices became almost mannerist in mood.

In the 1880s, the home buyers wanted houses characterized by eccentricity, exaggeration, invention.

The Queen Anne Style is the architectural style born between 1880s and 1890s.

The main features are the emphasized presence of horizontal elements and no vertical ones, the presence of surfaces decorated in different ways, the most typical being the so-called scaled surface. Other features are the presence of a decorated triangular front tympanum, a portico raised above the street level and decorations that resemble lace work. Sometimes Queen Anne Style buildings may have a turret.

Compared to the designs of the Eastlake Style period, the designs became somewhat more controlled, at least compared to the wild manipulations of the late 1880s. They are characterized by large internal floors and different shapes of the internal rooms. Different materials were used for the exterior, including intricate pattern shingle work and fancy plasters. There was an increasing movement toward control and refinement.

In particular, in San Francisco, Queen Anne houses brought back gable roofs, succeeding the flat roofs of the earlier Italianate and Eastlake houses.

The Shingle Style can be considered the last of the architectural styles of theVictorian period. This style was popularized by Bernard Maybeck and Julia Morgan, two very famous architects in California. This style is particularly widespread in Berkeley and Oakland but also in San Francisco.

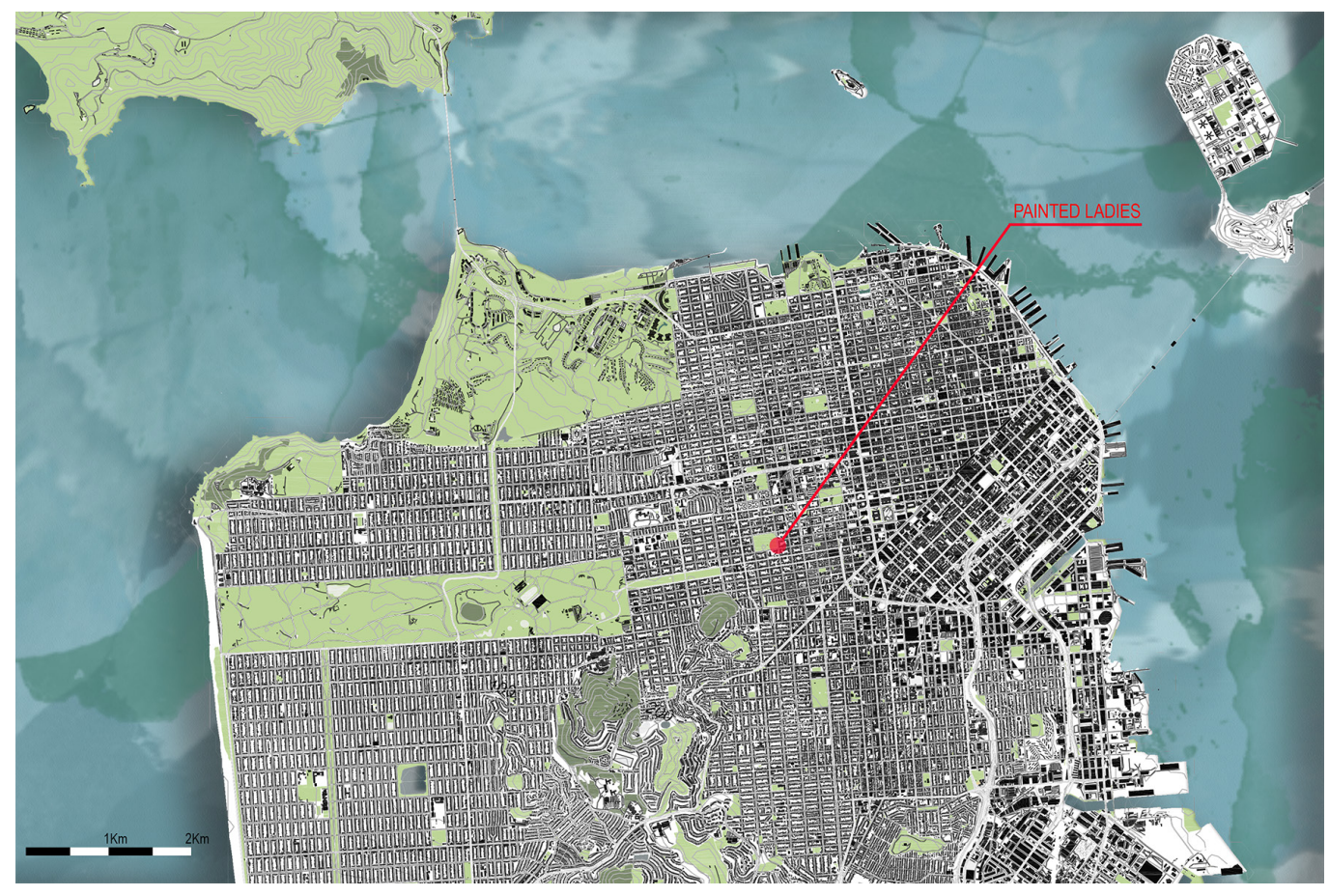


Originating in England and New England, this style found support among a San Francisco's educated elite in the 1890s. The Shingle Style is distinctly American in its wood construction typically blending into natural surroundings.

The houses of Shingle Style were usually built on stone foundations that seem to emerge from bedrock and for this reason the structure seemed one with the ground. To strengthen the interaction with the outside there were large windows, balconies and porches. Since these are houses characterized by complex and varied forms, they were usually characterized by high construction costs and for this reason it was not a style that spread mass vernacular housing.

Unlike the other styles of the Victorian Era, the Shingle Style did not favour the decoration of detail but rather favored complex forms of the whole.

To complete the complex shapes there were complex roofs.

Gables were arranged asymmetrically, although paired or symmetrically arranged cross gables were not unheard of. About one quarter of Shingle Style houses had a side gabled roof with a tower placed in the front.

It is therefore clear how incredibly varied the architectural landscape of the Victorian period was. For this reason, it is important to preserve its memory. Although there were once some 58,000 Victorian homes in the city, many of them were destroyed in the devastating 1906 earthquake and fire. Today just 14,000 remain.

In particular, this research focused on the analysis of buildings called Painted Ladies (figs. 3,4). Originally, the houses of the Victorian period were painted a chalky white to mask their redwood structure and look more like stone.

Subsequently, during the first and second World Wars, many buildings were coated in a blue colour. And in such a way they remained until the 1960s, when artists like Butch Kardum and a band of colorists, as they were called, began to experiment with bright colours on the facades of these Victorian houses. The colours varied from green to vermilion, from gold to turquoise.

For this reason, these buildings were labelled 'painted ladies'. The most famous examples, in fact, are a group of Queen Anne style houses on Steiner Street near Alamo Square, built in 1890 by Matthew Kavanaugh and painted in pastel colour.

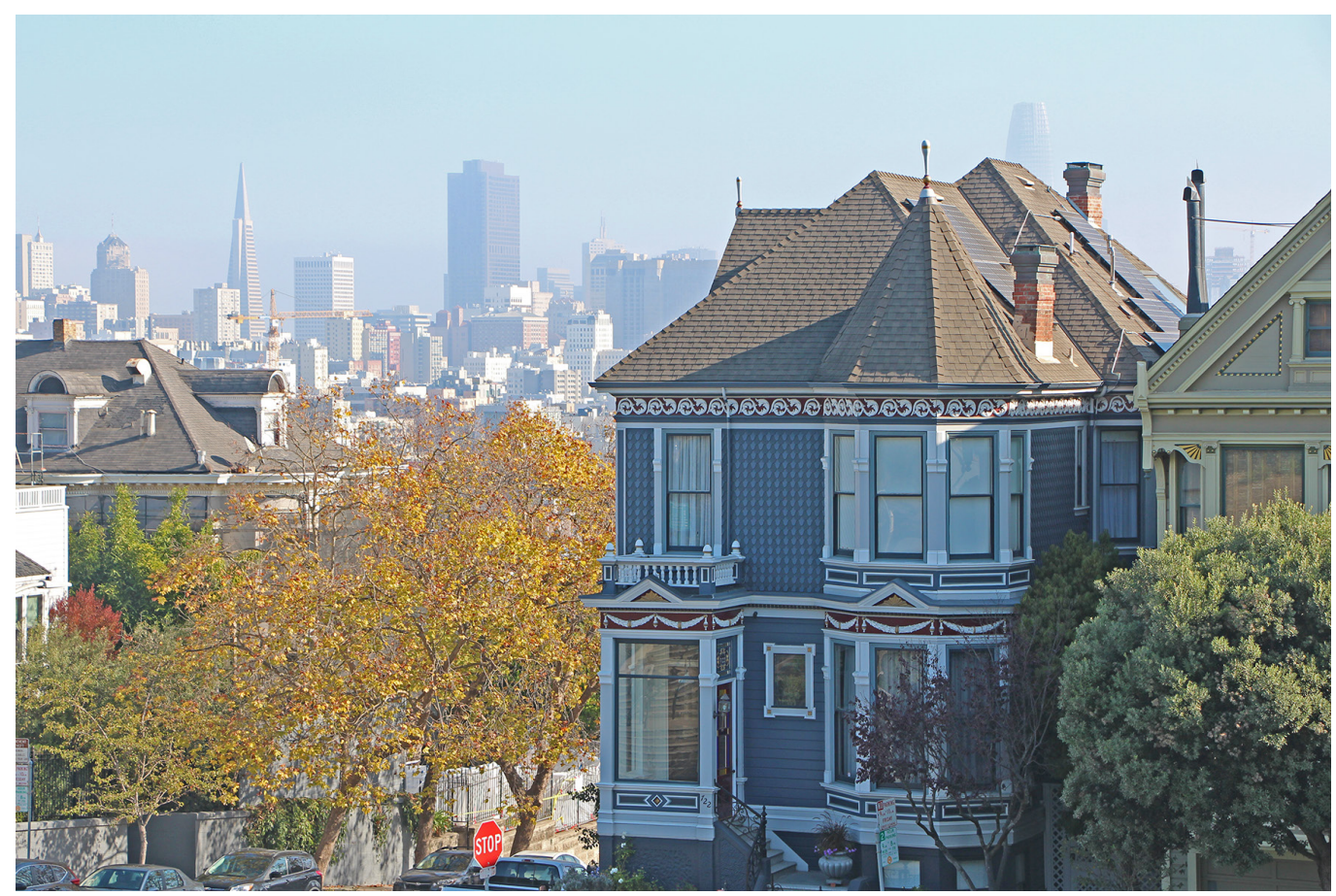


The famous 'Painted Ladies of San Francisco', also known as the 'Seven Sisters', are characterized by unique colours and details; they strictly follow Queen Anne architectural style. Their distinctive factor includes an asymmetrical façade with a dominant top front-facing gable, cantilevered out beyond the plane of the wall below.

Other elements of characterization are overhanging roofline and detailed support, richly elaborated gables, a dominant round corner tower, painted classical columns, spindles and balustrades.

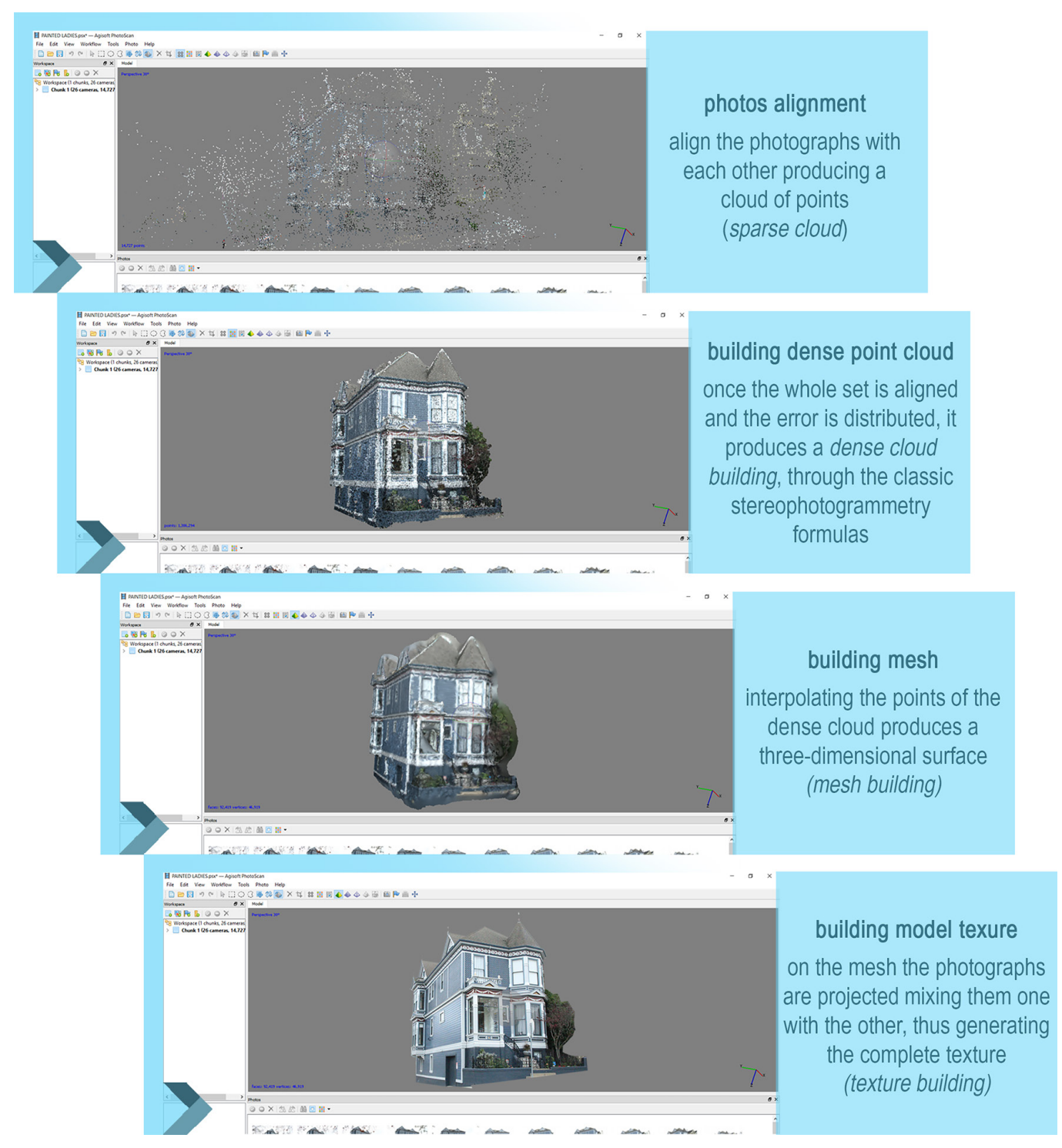

There are also complex stain-glass panelling and different wall textures, including patterned wood shingles shaped into varying designs.

In the course of time the 'Painted Ladies' have come to symbolize San Francisco architectural traditions and have become a key element of the city's landscape.

The folk rebirth of San Francisco's Painted Ladies not only catalysed the growing interest in Victorian architecture, but also helped widen the appreciation of all historic houses for decades to come. For this reason, it is important to preserve this architectural heritage. The first building detected and modelled is the building located in the corner between Grove St. and Steiner St. (fig. 5). 
The photographic campaign was carried out on the building, using the parallel photographic shooting technique and convergent axis photographic shooting technique, both at street level and from the level of the hill present at the front of the Painted Ladies. The indirect survey was fundamental for the measurement of the external façades. The camera - Canon Reflex Eos 600D camera - has been located in 72 stations using the same focal length, in order to photograph all the points of the façade and to fill, as much as possible, the shadow cones, considering the multiple difficulties due to the presence of vegetation and the busy street. The photographs acquired were imported into photogrammetric modelling software, Metashape of Agisoft. Reference points were selected on the building like corners which are easily identifiable and separable.

Through feature extraction and matching operations, as the recognition of Tie Points which are common to more images, and their gathering thanks to Scale-Invariant Feature Transform algorithm we achieved a model composed by TiePoints.

The 3D model is helpful for the orientation, the sparse point cloud, from which the dense matching followed: during this phase the algorithm allowed to generate a points made model of the interested object called dense point cloud, once analysed orientated photograms with an established field partition.

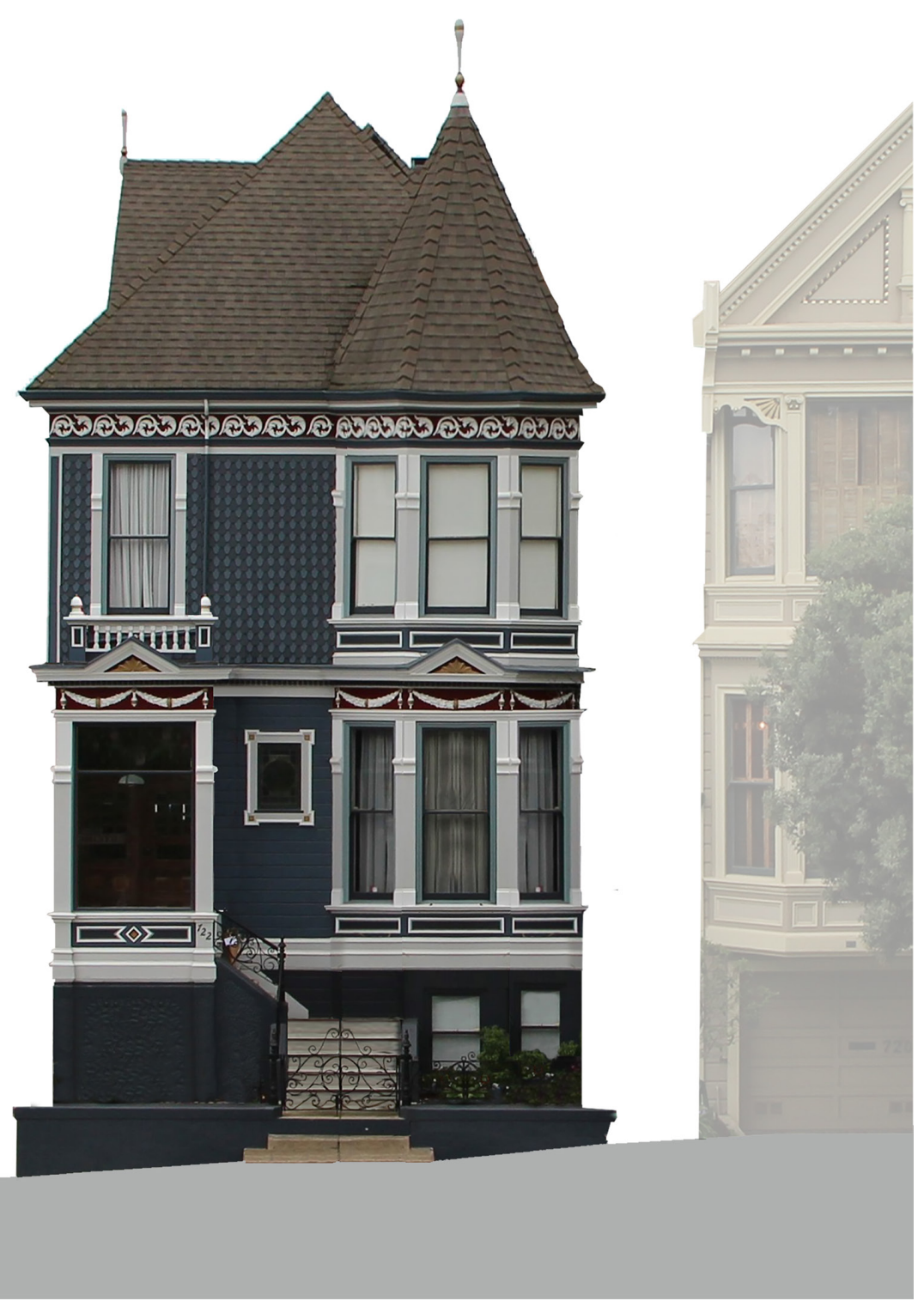


Then the referencing and scaling of the model was done by means of measurements or known points recollected in the field (figure 6).

The phases that led to the construction of the point cloud are as follows:

- photo alignment: align the photographs with each other producing a cloud of points (sparse cloud);

- camera calibration, adaptive camera model fitting;

- building dense point cloud: once the whole set is aligned and the error is distributed, it produces a dense cloud building, through the classic stereophotogrammetry formulas.

Once the point cloud was generated, it was exported in a model in .rcp format, compatible to be imported into the Revit software.

Parametric modelling was performed with the Revit software, with the creation of Revit families useful for the generation of models of different Victorian Queen Anne Style buildings. Particular attention has been paid to the modelling of the façade, which is highlighted in the figures (figs. 7, 8). A database of elements accessible at all times has been generated, in which dimensional and material changes can be made by varying one or more parameters. In this way it is possible to quickly generate new models of buildings identified by the same elements that characterize the Victorian style.

The creation of a kind of model which is measurable and navigable is clearly a great advantage not only to document and monitor buildings, but also to the evaluation procedure, intended to prevent and reduce the vulnerability.

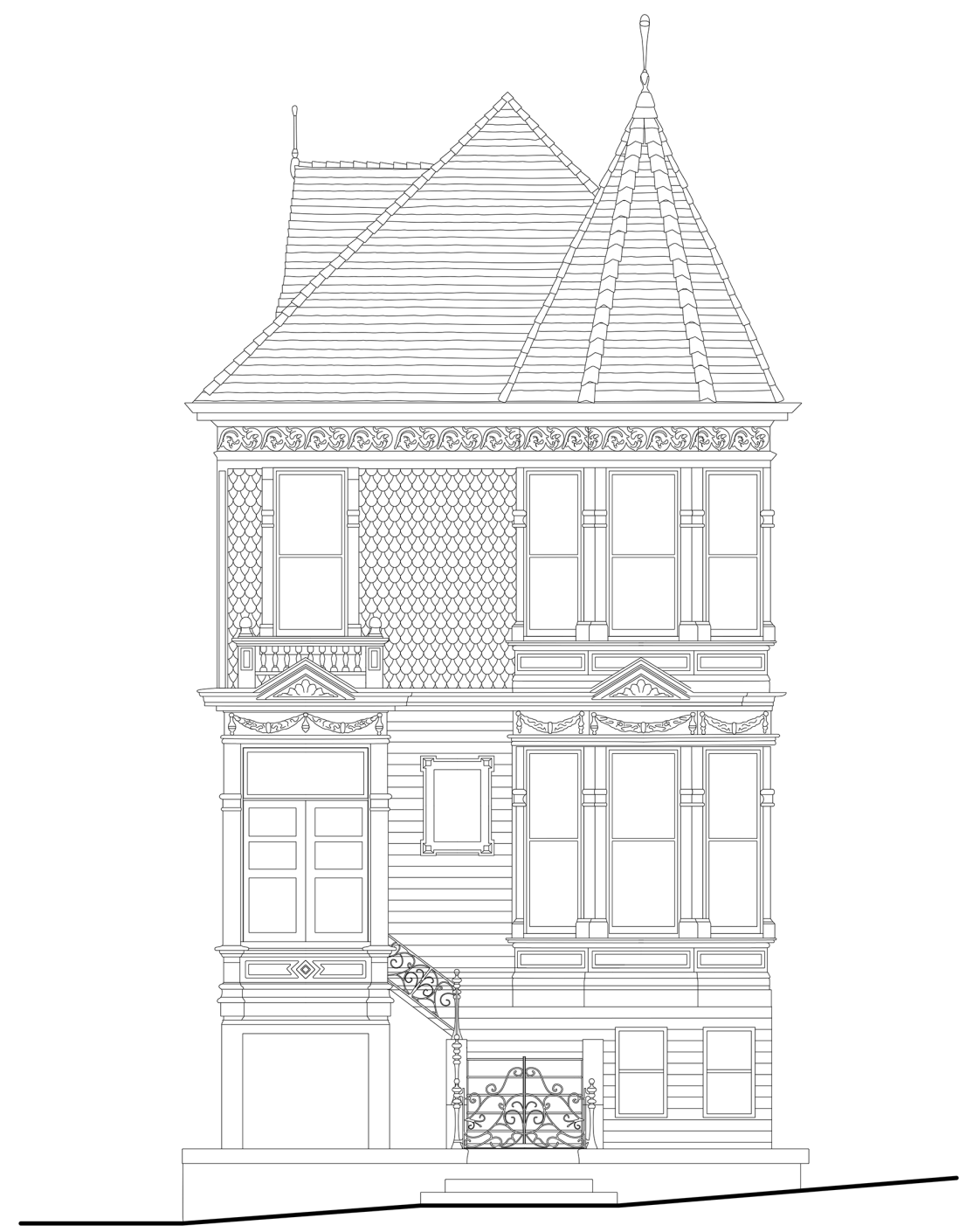




\title{
References
}

Attenni Martina, Bartolomei Cristiana, Inglese Carlo, Ippolito Alfonso, Morganti Caterina, Predari Giorgia (2017). Low cost survey and heritage value. In SCIRES-IT, 7, 2, 2017, pp. II5-I32.

Baird Joseph (1962). Time's Wondrous Changes: San Francisco Architecture, 1776- 19 1 5. San Francisco: California Historical Society. Barth Gunther (1980). City People:The Rise of Modern City Culture in Nineteenth-Century America. New York: Oxford University Press.

Beach John (1976). The Bay Area Tradition, 1890-1918. New York: Oxford University Press.

Books Bruce Curt, Aidala Thomas (1974). Great Houses of San Francisco. New York: Alfred A. Knopf.

Cipriani Luca, Fantini Filippo, Bertacchi Silvia (20 16). 3D Digital Models for Scientific Purpose: Between Archaeological Heritage and Reverse Modelling. In Ippolito Alfonso (ed.). Handbook of Research on Emerging Technologies for Architectural and Archaeological Heritage. Hershey PA: IGI Global, 2016, pp. 29I-32I.

Docci Mario, Bianchini Carlo (2016). The role of virtual 3D models in the conservation of architectural and archaeological heritage. In Disegnare. Idee immagini, XXVII, 53, 20I6, pp. 3-6.

Grow Lawrence, von Zwek Dina (1984). American Victorian: A Style and Source Book. New York:The Main Street Press/Harper \& Row

Hansen Gladys (1975). San Francisco Almanac. San Francisco: Chronicle Books.

Kemp Jim (1985).Victorian Revival in Interior Design. New York: Quarto Marketing Ltd./Simon \& Schuster.

Morganti Caterina, Bartolomei Cristiana (2017). Digital documentation and archiving low cost: La Habana Vieja in Cuba. In The International Archives of the Photogrammetry, Remote Sensing and Spatial Information Sciences, XLII-2/w8, 20 I 7, pp. I 63- I 70.

Moss Roger (1988). Lighting for Historic Buildings: A Guide to Selecting Reproductions. Washington, D.C.:The Preservation Press. Muthesius Stephen (1972). The High Victorian Movement in Architecture 1850- 1870. London: Routledge, Kegan Paul.

Remondino Fabio, Rizzi Alessandro (20 I0). Reality-based 3D documentation of natural and cultural heritage sites - techniques, problems, and examples. In Applied Geomatics, 2, 3, 20 I0, pp. 85- 100

von Rosensteil Helen, Winkler Gail Caskey (1988). Floor Coverings for Historic Buildings. Washington, D.C.: Preservation Press.

Waldhorn Judith Lynch, Woodbridge Sally (1978). Victoria's Legacy: Tours of San Francisco Bay Area Architecture. San Francisco: 10I Productions.

Wellikoff Alan (1984). The American Historical Supply Catalogue. New York: Schocken Books.

Woodbridge Sally (1988). California Architecture. San Francisco: Chronicle Books.

\begin{abstract}
Authors
Caterina Morganti, Alma Mater Studiorum Università di Bologna, caterina.morganti4@unibo.it

Cecilia Mazzoli,Alma Mater Studiorum Università di Bologna, cecilia.mazzoli2@unibo.it

Cristiana Bartolomei, Alma Mater Studiorum Università di Bologna, cristiana.bartolomei@unibo.it

Dominique Rissolo, University of California, San Diego, drissolo@ucsd.edu

Falko Kuester, University of California, San Diego, fkuester@ucsd.edu
\end{abstract}

To cite this chapter. Morganti Caterina, Mazzoli Cecilia, Bartolomei Cristiana, Rissolo Dominique, Kuester Falko (2020). Preserve the memory of San Francisco's Victorian Architecture. In Arena A., Arena M., Brandolino R.G., Colistra D., Ginex G., Mediati D., Nucifora S., Raffa P. (a cura di). Connettere. Un disegno per annodare e tessere. Atti del $42^{\circ}$ Convegno Internazionale dei Docenti delle Discipline della Rappresentazione/Connecting. Drawing for weaving relationships. Proceedings of the 42th International Conference of Representation Disciplines Teachers. Milano: FrancoAngeli, pp. 2468-2476. 